\title{
Penerapan Metode Weigth Product Untuk Rekomendasi Penempatan Praktek Kerja Industri (Study Kasus: SMK Muhammadiyah 01 Pekanbaru)
}

\author{
Doni Winarso $^{\text {a }}$, Fitri Nurita ${ }^{\mathrm{b}}$, Syahril $^{\mathrm{c}}$ \\ ${ }^{\text {a} P r o d i ~ S i s t e m ~ I n f o r m a s i, ~ f a k u l t a s ~ I l m u ~ K o m p u t e r, ~ U n i v e r s i t a s ~ M u h a m m a d i y a h ~ R i a u, ~ d o n i w i n a r s o @ u m r i . a c . i d ~}$ \\ bProdi Sistem Informasi, fakultas Ilmu Komputer, Universitas Muhammadiyah Riau, fitrinurita@umri.ac.id \\ cProdi Sistem Informasi, fakultas Ilmu Komputer, Universitas Muhammadiyah Riau, syahril@umri.ac.id
}

\begin{abstract}
This research aims to build a decision support system (DSS), that is used to recommend a place of Industrial Practice (in Indonesia known as PRAKERIN) for students who will plunge into the world of industrial world (DUDI). The reason why this research is raised is due to the frequent difficulties faced by students in determining which location suits their needs. In this research, location selection is calculated using weighted product (WP) method. WP method is one of Multiple Criteria Decision Making (MCDM) method that can solve one dimensional and multi dimensional problems. From the results of research conducted found that the WP method can help determine the location prakerin for students, so for students it is very helpful to them in determining prakerin location in accordance with the criteria specified.
\end{abstract}

Keywords: PRAKERIN, decission support systems, weight product

\begin{abstract}
Abstrak
Penelitian ini bertujuan untuk membangun sebuah system pendukung keputusan (SPK) yang digunakan untuk merekomendasikan tempat Praktek Kerja Industri (PRAKERIN) bagi para siswa yang akan terjun ke dunia usaha dunia industri (DUDI). Alasan mengapa penelitian ini diangkat adalah dikarenakan seringnya muncul kesulitan bagi para siswa dalam menentukan lokasi mana yang sesuai dengan kebutuhan mereka. Dalam penelitian ini pemilihan lokasi dihitung menggunakan metode weighted product (WP).. Metode WP merupakan salahsatu dari metode Multiple Kriteria Decission Making (MCDM) yang dapat menyelesaikan permasalahan satu dimensi maupun multi dimensi. Dari hasil penelitian yang dilakukan didapatkan bahwa metode WP dapat membantu menentukan lokasi prakerin bagi para siswa, sehingga bagi siswa hal ini sangat membantu mereka dalam menentukan lokasi prakerin sesuai dengan kriteria yang ditentukan.
\end{abstract}

Kata kunci: PRAKERIN, sistem pendukung keputusan,weigted product

(C) 2018 Jurnal RESTI

\section{Pendahuluan}

Perkembangan Teknologi Informasi (TI) yang sangat pesat dewasa ini, memberi pengaruh yang signifikan terhadap perkembangan disegala aspek kehidupan, salah satu aspek tersebut adalah bidang pendidikan. Pengolahan data sekolah terutama di Sekolah Menengah Kejuruan (SMK) sangat memerlukan peran TI. Hal ini dikarenakan SMK merupakan sekolah yang memiliki banyak kegiatan dibandingkan dengan sekolah umum yang sederajat. Diantara banyak kegiatan tersebut salah satunya adalah Praktek Kerja Industri (PRAKERIN). Program magang atau PRAKERIN telah diatur dalam undang-undang no.13 tahun 2003 tentang ketenagakerjaan khususnya pasal 21-30[1], dan lebih spesifiknya diatur dalam peraturan menteri tenaga kerja dan transmigrasi no. Per.22/men/ix/2009 tentang penyelenggaraan pemagangan di dalam negeri [2].
Permasalahan yang sering muncul dalam kegiatan PRAKERIN ini adalah kesulitan siswa dalam menentukan tempat atau lokasi untuk PRAKERIN yang sesuai dengan jurusan dan kondisinya, sehingga banyak dari siswa yang telah mengikuti prakerin hasilnya tidak maksimal dikarenakan beberapa hal diantaranya, Jarak dari rumah ke lokasi prakerin jauh sehingga sering terdapat keluhan dari DU/DI atas keterlambatan kehadiran siswa. Masalah berikutnya adalah jumlah siswa yang diterima dalam satu lokasi prakerin sudah cukup banyak sehingga kegiatan yang mereka lakukan tidak cukup maksimal. Kemudian permasalahn juga timbul pada tingkat kesulitan atau beban kerja yang diberikan kepada siswa oleh pihak DU/DI tidak terlalu dipahami oleh siswa. Permasalahan klasik seperti jam kerja yang tidak sesuai dengan keinginan para siswa.

Agar penentuan tempat dan lokasi prakerin dapat dilakukan secara efektif dan menghasilkan keputusan

Diterima Redaksi : 05-06-2017 | Selesai Revisi : 30-07-2018 | Diterbitkan Online : 02-08-2018 
yang cepat dan tepat maka diperlukan sebuah sistem terbaik dari banyak alternatif yang ada dengan cara dan metode yang tepat untuk mengatasinya. Salah satu memberi bobot setiap kriteria untuk alternatif tersebut metode yang dapat digunakan untuk membantu [8]. menyelesaikan permasalahan dalam bursa kerja adalah weigted product(WP) [3]. WP merupakan salah satu metode Multi Cretia decision making (MCDM). MCDM merupakan teknik pengambilan keputusan dari beberapa pilihan alternative yang ada [3]. Dalam MCDM mengandung unsur kriteria, objektif dan tujuan.

Berdasarkan permasalahan yang diuraikan diatas, maka pada penelitian ini dilakukan analisis dan implementasi sistem pendukung keputusan yang dapat digunakan oleh siswa dalam merekomendasikan tempat prakerin menggunakan metode weighted product (WP).

\section{Tinjauan Pustaka}

\subsection{Praktek Kerja Industri (PRAKERIN)}

PRAKERIN merupakan program Sekolah Menengah Kejuruan (SMK) dengan mengutamakan keahlian dan ketrampilan yang telah dipelajari disekolah. Praktek Kerja Industri (PRAKERIN) adalah suatu bentuk penyelenggaraan dari sekolah yang memadukan secara sistematik dan sinkron antara program pendidikan di sekolah dan program pengusahaan yang di peroleh melalui kegiatan bekerja secara langsung di dunia kerja untuk mencapai suatu tingkat keahlian profesional [4]. Praktek Kerja Industri (PRAKERIN) dilaksanakan dalam rangka meningkatkan mutu siswa-siswi SMK dan diharapkan dapat menciptakan tenaga yang kerja profesional.

\subsection{Sistem Pendukung Keputusan (SPK)}

Fajar nugraha dan kawan kawan mendefinisikan SPK sebagai alat bantu bagi para pengambil keputusan untuk memperluas kapabilitas para pengambil keputusan namun tidak untuk menggantikan penilaian para pengambil keputusan [5]. SPK merupakan sistem yang digunakan untuk mendukung pengambil keputusan manajerial dalam situasi keputusan tidak terstruktur[6]. SPK sifatnya hanya membantu para pengambil keputusan dalam menentukan pilihan dari sekian banyak alternatif berdasarkan kriteria dan pembobotan yang ditentukan, bukan sebagai pengganti pengambil keputusan dalam memutuskan suatu hal. Penelitian mengenai sistem sudah banyak dilakukan oleh para peneliti, diantaranaya adalah penelitian yang dilakukan oleh candra surya yang meneliti penilaian kinerja dosen menggunakan metode TOPSIS [6], fitriyani dan kawan-kawan juga melakukan penelitian pada topik SPK dengan judul penentuan beasiswa pada SMPN 6 pangkal pinang menggunakan metode SAW dan FMADM [7].

\subsection{Metode Weighted Product (WP)}

Metode WP adalah bentuk metode pendukung keputusan dimana metode ini mencari alternatif yang
Metode WP menggunakan perkalian untuk menghubungkan rating kriteria, dimana rating setiap kriteria harus dipangkatkan dulu dengan bobot kriteria yang bersangkutan. Proses ini seperti layaknya proses normalisasi [9].

Langkah-langkah metode WP dapat dijabarkan sebagai berikut [10]

1. Menentukan kriteria yang akan digunakan sebagai parameter penilaian

2. Menentukan Nilai preferensi dari decision making

3. Melakukan perhitungan nilai relative bobot awal (wj). Nilai bobot awal (w0) digunakan untuk menunjukkan tingkat kepentingan relative dari setiap kriteria.

$w_{j}=\frac{w_{0}}{\sum w_{0}}$

Dimana :

$w j=$ bobot Perbaikan

$w 0$ = bobot awal

$\sum w 0=$ Jumlah Bobot

4. Melakukan perhitungan nilai preferensi untuk setiap alternative vector $\mathrm{S}$ dengan rumus 1 berikut.

$s_{i}=\prod_{j=1}^{n}\left(x_{i j}\right) w_{j}$

$\mathrm{S}=$ preferensi alternative vector $\mathrm{S}$

$\mathrm{X}=$ nilai kriteria

$\mathrm{W}=$ bobot kriteria

$\mathrm{I}=$ alternative

$\mathrm{J}=$ kriteria

$\mathrm{N}=$ banyaknya kriteria

5. Melakukan perankingan

\section{Metodologi Penelitian}

Pada penelitian ini tahapan yang akan dilakukan dibagi kedalam 3 tahapan. Tahapan tersebut digambarkan dan dijelaskan pada Gambar 1.

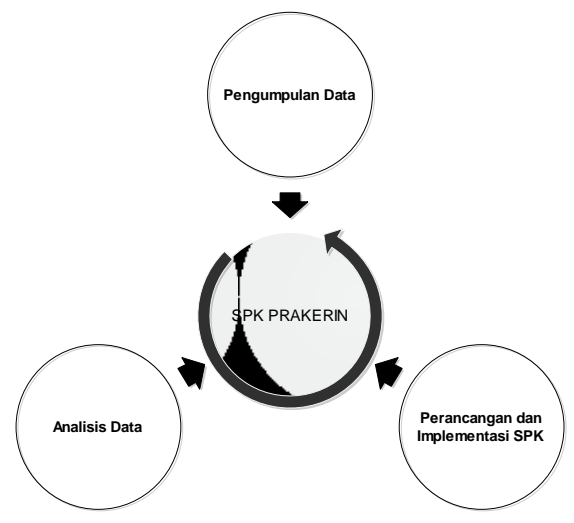

Gambar 1. Tahapan Penelitian 
Penjelasan dari Gambar 1 sebagai berikut.

1.Pengumpulan data

Pengumpulan data dilakukan dengan cara wawancara, menggunakan metode WP dan hasilnya akan observasi dan study literatur.Penelitian ini dilakukan di ditampilkan oleh sistem pendukung keputusan yang SMK Muhammadiyah 1 Pekanbaru. Data diambil dari dibangun.

bagian kesiswaan yang mengelola kegiatan prakerin. Data yang didapat terlebih dahulu di normalisasi untuk mendapatkan kriteria yang sesuai dengan permasalahan yang akan diselesaikan.

\section{Analisis Data}

Pada tahapan ini dilakukan analisis terhadap data yang diperoleh menggunakan metode WP. Analisis dilakukan dengan melakukan perhitungan menggunaan langkah-langkah WP yang dijelaskan pada landasan teori. Alat bantu yang digunakan pada analisis ini adalah menggunalan MS.Excel 2016.

\section{Perancangan dan Implementasi SPK}

Setelah melakukan analisa terhadap data dan metode WP yang digunakan, tahapan selanjutnya adalah merancang sistem pendukung keputusan. Pada tahapan ini perancangan SPK dilakukan menggunakan metode pengembangan perangkat lunak Waterfall. Waterfall merupakan model pengembangan sistem informasi yang sistematik dan sekuensial[11]. Adapun tahapan dalam metrode waterfall adalah Analysis, Design, Code, Test [12] . Tools yang digunakan dalam perancangan adalah Entity Relationship Diagram(ERD), Data Flow Diagram (DFD).

\section{Hasil dan Pembahasan}

Hasil dari penelitian yang dilaksanakan akan dijelaskan sebagai berikut

\subsection{Arsitektur SPK}

Arsitektur informasi (atau arsitektur teknologi informasi, arsitektur sistem informasi, infrastruktur teknologi informasi) adalah suatu pemetaan atau rencana kebutuhan-kebutuhan informasi di dalam suatu organisasi [5]. Arsitektur akan menjelaskan bagaimana proses sistem pendukung keputusan penentuan lokasi PRAKERIN menggunakan metode weighted product. Adapun arsitekturnya dapat dilihat pada Gambar 2.

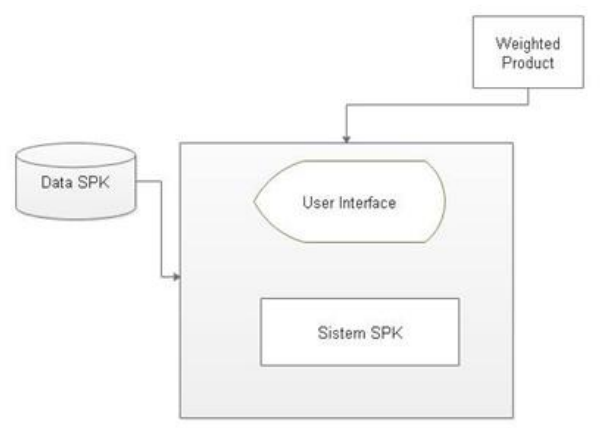

Gambar 2. Arsitektur SPK PRAKERERIN
Arsitektur SPK diatas menyajikan gambaran umum dari sistem yang akan dikembangkan. Data kriteria yang tersimpan dalam database akan dihitung 4.2 Permodelan Metode WP

WP pada sistem SPK yang dikembangkan berfungsi untuk membantu decission maker dalam menentukan lokasi prakerin yang sesuai kriteria, sehingga pada SPK ini kriteria juga ditentukan oleh decission maker, dalam hal ini adalah panitia Prakerin SMK Muhammadiyah 01 Pekanbaru. Kriteria yang digunakan pada penelitian ini dapat dilihat pada tabel 1 ..

Tabel 1. Tabel Kriteria

\begin{tabular}{lll}
\hline No & Kode Attribut & \multicolumn{1}{c}{ Attribut } \\
\hline 1 & A1 & Jarak \\
2 & A2 & Siswa yang dibutuhkan \\
3 & A3 & Beban Kerja \\
4 & A4 & Jam kerja per hari \\
5 & A5 & Waktu tempuh ke Lokasi \\
\hline
\end{tabular}

Decission maker memberikan bobot preferensi sebagai berikut, lihat Tabel 2 .

\begin{tabular}{cc} 
Tabel 2. Tabel Bobot Kriteria \\
\hline Nilai & Bobot \\
\hline 1 & $15 \%$ \\
2 & $20 \%$ \\
3 & $15 \%$ \\
4 & $20 \%$ \\
5 & $30 \%$ \\
\hline
\end{tabular}

Selanjutnya setiap kriteria diberikan nilai preferensi. Untuk kriteria jarak tempat tinggal dengan lokasi dan normalisasinya disajikan pada tabel 3.

Tabel 3. Tabel Nilai Jarak Tempat Tinggal dengan Lokasi

\begin{tabular}{ccc}
\hline Jarak & Lokasi & Keterangan \\
\hline$<5 \mathrm{Km}$ & Dekat & 3 \\
$6-10 \mathrm{Km}$ & Sedang & 2 \\
$>11 \mathrm{Km}$ & Jauh & 1 \\
\hline
\end{tabular}

Selanjutnya untuk kriteria jumlah siswa yang magang pada suatu tempat disajikan pada tabel berikut ini.

\begin{tabular}{ccc}
\multicolumn{3}{c}{ Tabel 4. Tabel Nilai Kriteria siswa yang dibutuhkan } \\
\hline Jumlah & Keterangan & Nilai \\
\hline 1 Orang & Sedikit & 3 \\
2 Orang & Sedang & 2 \\
3 Orang & Banyak & 1 \\
\hline
\end{tabular}

Untuk kriteria beban kerja disajikan pada tabel 5.

Tabel 5. Tabel Nilai Kriteria Beban Kerja

\begin{tabular}{cll}
\hline Tingkatan Tugas & Keterangan & Poin \\
\hline Ringan & Sedikit & 3 \\
Sedang & Sedang & 2 \\
Susah & Banyak & 1 \\
\hline
\end{tabular}


Doni Winarso, Fitri Nurita, Syahril

Jurnal RESTI (Rekayasa Sistem dan Teknologi Informasi) Vol. 2 No. 2 (2018) 566 - 571

Kriteria jam kerja disajikan pada tabel 6.

Tabel 6. Tabel Nilai Kriteria Jam Kerja

\begin{tabular}{ccc}
\hline Jam & Keterangan & Nilai \\
\hline 7 & Rendah & 3 \\
8 & Sedang & 2 \\
12 & Tinggi & 1 \\
\hline
\end{tabular}

Sedangkan alternatif lokasi prakerin yang digunakan pada penelitian ini adalah

Tabel 7. Table Alternatif PRAKERIN

\begin{tabular}{lll}
\hline & No & \multicolumn{1}{c}{ Kode } \\
Alternatif & \\
\hline 1 & A1 & PT.PRIMA NUSA GLOBALINDO \\
2 & A2 & PUSTAKA WILAYAH \\
3 & A3 & PT.PERTAMINA \\
4 & A4 & RSUD ARIFIN \\
5 & A5 & SMART COMPUTER \\
6 & A6 & CV.ASRI ENGGINEERING \\
& & CONSULTAN \\
7 & A7 & CV2K (WAN XP) \\
8 & A8 & PT.LAGIO \\
9 & A9 & AMIK TRI DARMA \\
10 & A10 & BADAN PERTAHANAN \\
11 & A11 & UPAYA TEKNIK \\
12 & A12 & DINAS PENDIDIKAN RIAU \\
\hline
\end{tabular}

\begin{tabular}{rlccccc}
\hline No & Kode & C1 & C2 & C3 & C4 & C5 \\
\hline 8 & A8 & 1.00 & 3.00 & 2.00 & 3.00 & 1.00 \\
9 & A9 & 3.00 & 3.00 & 3.00 & 3.00 & 2.00 \\
10 & A10 & 3.00 & 2.00 & 2.00 & 2.00 & 2.00 \\
11 & A11 & 3.00 & 1.00 & 2.00 & 2.00 & 3.00 \\
12 & A12 & 2.00 & 2.00 & 2.00 & 2.00 & 2.00 \\
\hline
\end{tabular}

Tahap berikutnya adalah melakukan perhitungan nilai preferensi untuk setiap alternative vector $S$ dengan rumus 1 diatas. Setelah dilakukan perhitungan maka didapat hasil dan perangkingan seperti yang disajikan pada tabel 10 .

Tabel 10. Table Perhitungan WP

\begin{tabular}{rlccr}
\hline No & Kode & Bobot Vector S & Bobot Vector V & Pilihan \\
\hline 1 & A1 & 2.449 & 0.092 & 5 \\
2 & A2 & 2.500 & 0.094 & 3 \\
3 & A3 & 1.783 & 0.067 & 11 \\
4 & A4 & 2.500 & 0.094 & 4 \\
5 & A5 & 2.544 & 0.096 & 2 \\
6 & A6 & 1.922 & 0.073 & 10 \\
7 & A7 & 1.933 & 0.073 & 9 \\
8 & A8 & 1.565 & 0.059 & 12 \\
9 & A9 & 2.766 & 0.104 & 1 \\
10 & A10 & 2.259 & 0.085 & 7 \\
11 & A11 & 2.285 & 0.086 & 6 \\
12 & A12 & 2 & 0.075 & 8 \\
\hline
\end{tabular}

Berikut akan dilakukan perhitungan manual sistem Dari hasil yang disajikan pada tabel di atas terlihat pendukung keputusan menggunakan metode wighted bahwa saran yang diberikan untuk tempat prakerin product $(W P)$. Data yang digunakan untuk perhitungan adalah pada kode alternatif A9 yaitu AMIK Tri Darma. manual ini disajikan pada Tabel 8.

Tabel 8. Tabel Data PRAKERIN

\begin{tabular}{cllclcc}
\hline No & Kode & C1 & C2 & C3 & C4 & C5 \\
\hline 1 & A1 & $1 \mathrm{~km}$ & 2 org & sedang & 8 jam & 3 menit \\
2 & A2 & $3.9 \mathrm{~km}$ & 2 org & Ringan & 8 jam & 11 menit \\
3 & A3 & $3.9 \mathrm{~km}$ & 1 org & Susah & 12 jam & 10 menit \\
4 & A4 & $3.7 \mathrm{~km}$ & 1 org & Sedang & 7 jam & 10 menit \\
5 & A5 & $1.3 \mathrm{~km}$ & 1 org & Ringan & 12 jam & 5 menit \\
6 & A6 & $2.3 \mathrm{~km}$ & 3 org & Susah & 8 jam & 7 menit \\
7 & A7 & $0.55 \mathrm{~km}$ & 1 org & Susah & 12 jam & 2 menit \\
8 & A8 & $17 \mathrm{~km}$ & 1 org & Sedang & 7 jam & 38 menit \\
9 & A9 & $4.2 \mathrm{~km}$ & 1 org & Ringan & 7 jam & 12 menit \\
10 & A10 & $2.8 \mathrm{~km}$ & 2 org & Sedang & 8 jam & 10 menit \\
11 & A11 & $2.3 \mathrm{~km}$ & 3 org & Sedang & 8 jam & 8 menit \\
12 & A12 & $5.1 \mathrm{~km}$ & 2 org & Sedang & 8 jam & 13 menit \\
\hline
\end{tabular}

Tabel 8 merupakan tabel data awal yang di dalamnya terdapat data alternatif lokasi PRAKERIN yang dapat dipilih oleh siswa. Kemudian selanjutnya dilakukan
normalisasi terhadap data sehingga dapat dilihat pada tabel 9 .

Tabel 9. Tabel Normalisasi Data PRAKERIN

\begin{tabular}{rlccccc}
\hline No & Kode & C1 & C2 & C3 & C4 & C5 \\
\hline 1 & A1 & 3.00 & 2.00 & 2.00 & 2.00 & 3.00 \\
2 & A2 & 3.00 & 2.00 & 3.00 & 2.00 & 2.00 \\
3 & A3 & 3.00 & 3.00 & 1.00 & 1.00 & 2.00 \\
4 & A4 & 3.00 & 3.00 & 2.00 & 3.00 & 2.00 \\
5 & A5 & 3.00 & 3.00 & 3.00 & 1.00 & 3.00 \\
6 & A6 & 3.00 & 1.00 & 1.00 & 2.00 & 3.00 \\
7 & A7 & 3.00 & 3.00 & 1.00 & 1.00 & 3.00
\end{tabular}

\subsection{Perancangan}

Analisis yang dilakukan kemudian diterjemahkan kedalam SPK yang berbasis komputer. Metode pengembangan perangkat lunak yang digunakan adalah metode waterfall.

\subsubsection{Analisis Kebutuhan Sistem}

Kebutuhan sistem SPK PRAKERIN yang terkait dengan data penelitian yaitu data siswa, data tempat prakerin, data kriteria, pembobotan, jumlah siswa berdasarkan tempat prakerin. Sedangkan untuk analisis kebutuhan fungsional sistem SPK PRAKERIN yaitu, proses login, pengelolaan data siswa, pengelolaan data tempat prakerin, pengelolaan SPK.

\subsubsection{Desian System}

Tahapan desain digunakan untuk menggambarkan hasil dari sistem SPK Prakerin yang dikembangkan. Desain yang dibuat menjadi acuan dalam pengembangan sistem SPK ini. Adapun kebutuhan desain sistem SPK adalah Data Flow Diagram, Entity Relationship Diagram, desain output, dan desain input .

\section{Context Diagram}

Context diagram (Gambar 3) menggambarkan entitas dan proses data flow secara umum dari SPK prakerin yang dikembangkan. Terdapat 2 entitas yang terlibat yaitu siswa yang dapat melakukan input data siswa dan

Jurnal RESTI (Rekayasa Sistem dan Teknologi Informasi) Vol. 2 No. 2 (2018) 566 - 571 
Doni Winarso, Fitri Nurita, Syahril

Jurnal RESTI (Rekayasa Sistem dan Teknologi Informasi) Vol. 2 No. 2 (2018) 566 - 571

input data prakerin. Sedangkan entitas yang kedua adalah panitia prakerin. Panitia ini terdiri dari majelis guru yang ditunjuk dan tata usaha.

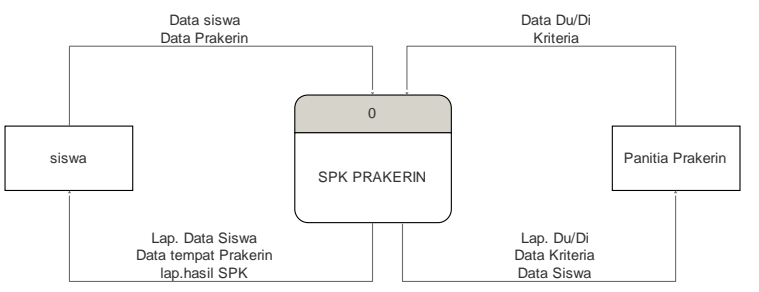

Gambar 3. Context Diagram SPK PRAKERIN

2. Data Flow Diagram SPK Prakerin

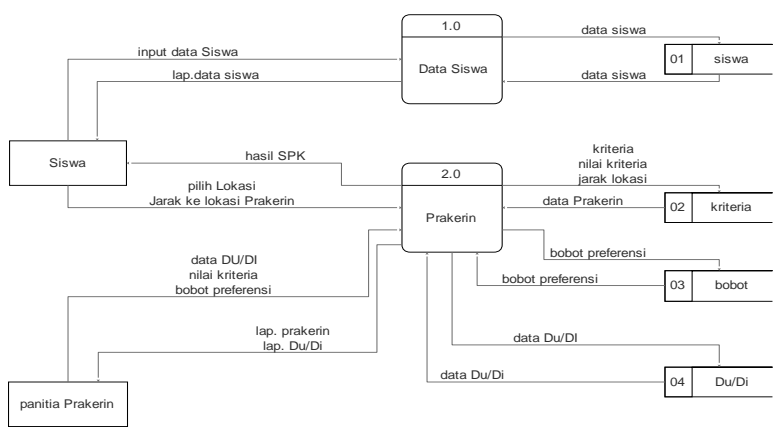

Gambar 4. Data Flow Diagram (DFD) level 1 SPK Prakerin

DFD level 1 terdiri dari 2 proses utama yaitu proses untuk mengelola data siswa, dan mengelola data prakerin. Pada DFD di atas juga terlihat data store untuk menampung data yang mengalir dari entitas ke proses. Data store tersebut adalah siswa, kriteria , bobot dan data store untuk Du/Di.

\section{Entity Relationship Diagram (ERD) SPK Prakerin}

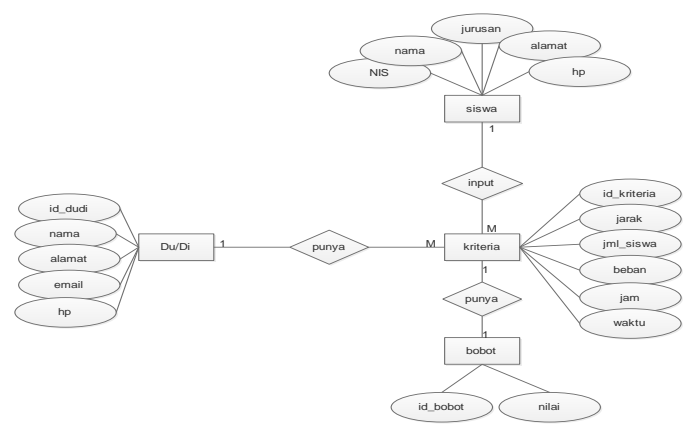

Gambar 5. ERD SPK Prakerin

\section{Rancangan Input}

Rancangan input terdiri dari rancangan halaman utama siswa, rancangan halaman utama panitia, rancangan input data siswa, rancangan SPK Prakerin

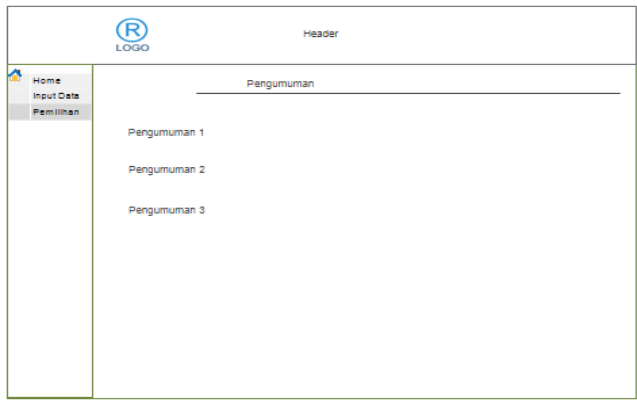

Gambar 6.Rancangan Halaman utama Siswa

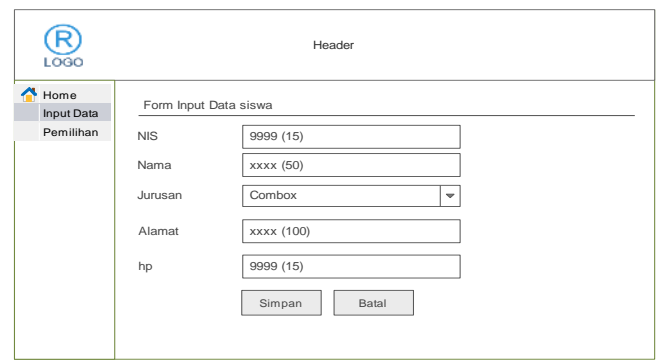

Gambar 7. Rancangan Halaman Input Data Siswa

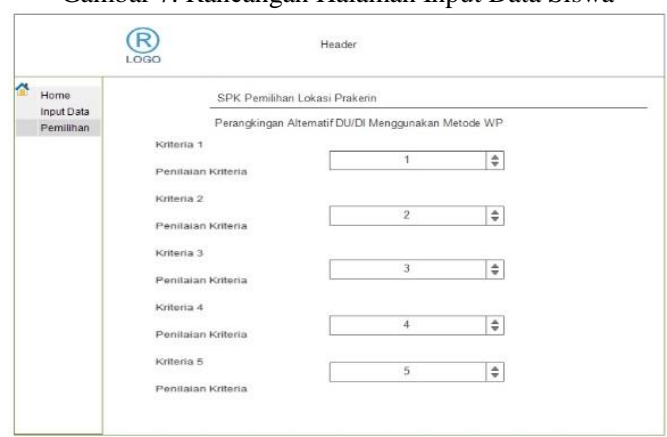

Gambar 8. Perhitungan dan Perangkingan SPK Prakerin

\subsubsection{Implementasi SPK Prakerin}

Implementasi SPK Prakerin dilakukan dengan menggunakan bahasa pemrograman PHP dan DBMS Mysql.

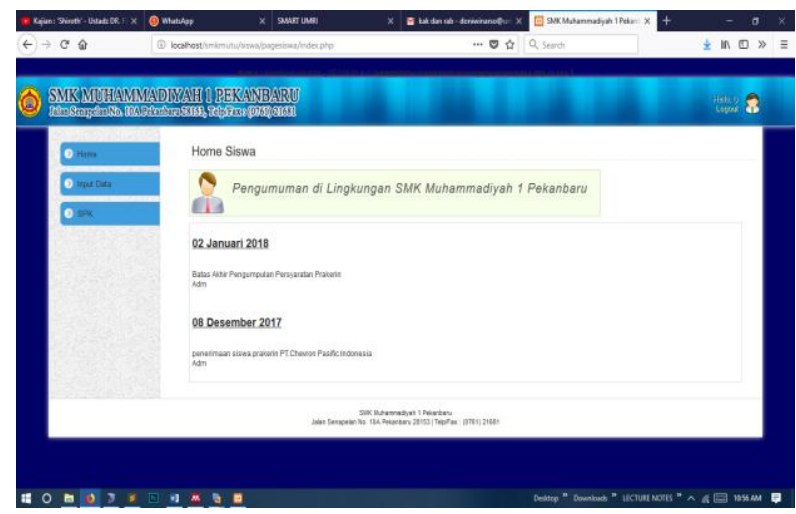

Gambar 9. Gambar Implementasi Halaman Home 


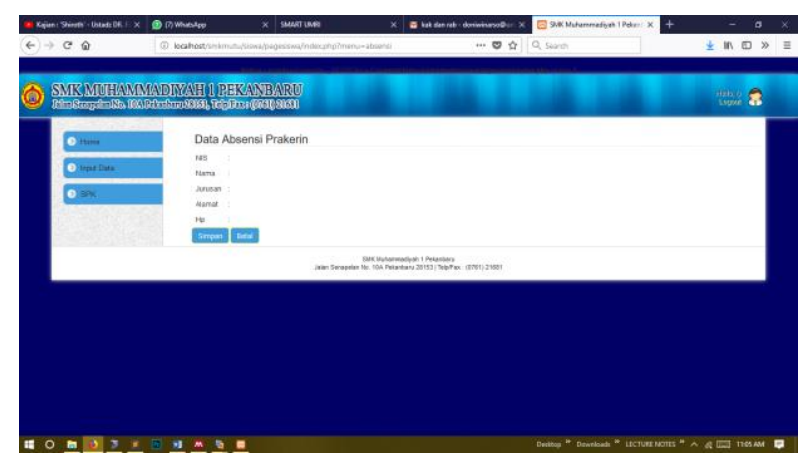

Gambar 10. Gambar Input Data Siswa

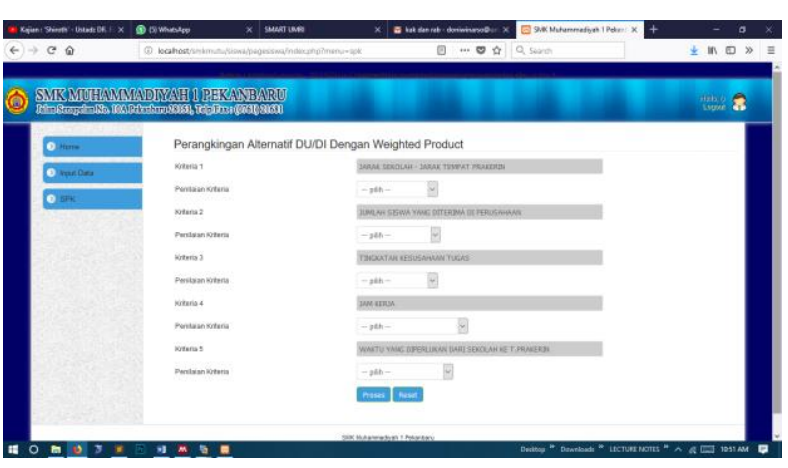

Gambar 11. Gambar Implementasi Halaman SPK

\section{Kesimpulan}

Telah dilakukan penelitian yang mengujikan penggunaan metode Weighted Product (WP) dalam menentukan lokasi prakerin

\subsection{Simpulan}

Telah dilakukan penelitian menggunakan metode WP dapat digunakan untuk membantu siswa dalam menentukan lokasi prakerin berdasarkan kriteria yang telah ditentukan.

\subsection{Saran}

Saran untuk penelitian ini perlu dilakukan perbandingan untuk mengetahui tingkat akurasi dan kecepatan antara metode WP dengan metode lainnya.

\section{Ucapan Terima Kasih}

Terimakasih kepada kepala sekolah SMK Muhammadiyah 01 atas izin yang diberikan. Ucapan terimakasih juga disampaikan kepada guru dan panitia prakerin. Dan kepada semua pihak yang telah membantu dan memberi dukungan sehingga penelitian ini dapat diselesaikan.

\section{Daftar Rujukan}

[1] Kementrian Tenaga Kerja, Undang-undang nomor 13 tahun 2003 tentang Ketenagakerjaan. 2002.

[2] Permenaker, Peraturan Menteri Tenaga Kerja Dan Transmigrasi Republik Indonesia Nomor Per.22/Men/Ix/2009 Tentang Penyelenggaraan Pemagangan Di Dalam Negeri.
2009.

[3] R. E. Stok and R. Yustina, "Penerapan Multi-Criteria Decision Making Dalam," J. Tek. Ind., vol. 2, pp. 1-12, 2000.

[4] Kementrian Pendidikan dan Kebudayaan, SK-Mendikbud-no323-U-1997-tentang-PSG. 1997.

[5] F. Nugraha, B. Surarso, and B. Noranita, "Sistem Pendukung Keputusan Evaluasi Pemilihan Pemenang Pengadaan Aset dengan Metode Simple Additive Weighting ( SAW )," J. Sist. Inf. Bisnis, vol. 02, no. 54, pp. 67-72, 2012.

[6] C. Surya, "Penilaian Kinerja Dosen Menggunakan Metode TOPSIS (Studi Kasus : AMIK Mitra Gama),” J. Resti, vol. 1, no. 1, pp. 9-18, 2017.

[7] P. Pajarini, "Penentuan Beasiswa Pada SMPN 6 Pangkalpinang Menggunakan Metode SAW dan Fuzzy Multi Attribute Decision Making," Rekayasa Sist. dan Teknol. Informasi), vol. 2, no. 1, pp. 437-443, 2018.

[8] M. Sulehu, "Sistem Pendukung Keputusan Pemilihan Layanan Internet Service Provider Menggunakan Metode Weighted Product ( Studi kasus: STMIK AKBA ) Marwa Sulehu STMIK AKBA," Indones. J. Netw. Secur., vol. 4, no. 4, pp. 55-60, 2015.

[9] D. Kusumawardani, "Sistem Pendukung Keputusan Penerima Bantuan Rumah Layak Huni Dengan Menggunakan Metode Weighted Product ( WP )."

[10] R. K. Niswatin, "Sistem Seleksi Penerimaan Mahasiswa Baru Menggunakan Metode Weighted Product ( Wp )," pp. 6-7, 2016.

[11] G. W. Sasmito, "Penerapan Metode Waterfall Pada Desain Sistem Informasi Geografis Industri Kabupaten Tegal," $J$. Inform. Pengemb. IT, vol. 2, no. 1, pp. 6-12, 2017.

[12] T. Romadhoni Eka Nur Ahmad, Widiyaningtyas and U. Pujianto, "Implementasi Model Waterfall Pada Pengembangan Sistem Informasi Alumni SMKN 1 Jenangan Ponorogo," Semin. Nas. Sist. Inf. Indones., no. November, pp. 445-452, 2015. 